\title{
Assessment of Well-Being at Work of Information Technology Professionals
}

\author{
Andréia Agostini, Anelise Viapiana Masiero, Lilia Aparecida Kanan \\ Post Graduate Program in Environment and Health \\ Universidade do Planalto Catarinense. \\ Av. Marechal Castelo Branco, 170. Lages. \\ Santa Catarina. Brazil.
}

\begin{abstract}
The study evaluated 283 Information Technology professionals of Brazilian technology companies regarding well-being at work. For data collection, the Psychosocial Well-Being Scale and the Maslach Burnout Inventory, associated with the Utrech Work Engagement Scale, were used. In general, positive evaluations for psychosocial well-being and engagement, as well as, lack of characteristics of Burnoutpredominated. The overall average in the Psychosocial Well-Being Scale was 4.93, with a standard deviation of 1.04. Men who work for one to five years presented higher values in the effectiveness dimension. Regarding engagement, the results were significant among men aged 40 and over. Professionals with shorter time of work in the organization presented lower indexes in the effectiveness dimension. These results corroborate the characteristics of Generation $Y$ regarding the greater commitment with the career than with the organization.
\end{abstract}

Keywords:Well-being; Well-being at Work; Information Technology.

\section{Introduction}

The new forms of work that have taken shape since the technological revolution have resulted in changes in the organizations, especially in relation to the process of innovation, increase of productivity and stimulation of competitiveness (Kanan\&Marcon, 2017; Zanelli\&Kanan, 2018). These transformations affect both the worker and the organization, and generate the need for adjustments, adaptations and resilient responses on the part of both, justified by the mental health of one (worker) and the achievement of results of another (organization) (Farsen, Costa \& Silva, 2018).

From the technological, structural, conjunctural and political changes that have impacted daily work, there are significant repercussions on all those involved in the productive system. And with Information Technology (IT), it was no different. For example, the outsourcing, whose effects still generate questioning (Fraga\& Barbosa, 2018), the impacts on the subjectivity and identity of the professional and the frailty in the work relationship (Dias \& Freitas, 2010), among others.

However, the technological revolution is not present only in the scientific reflection regarding workers' health. This milestone of contemporaneity is also present in the sociological approach, which translates technology as part of the physical organization of production, the organization of machines in the work environment and, finally, the division and organization of work (Silva et al., 2015).

In this context of technologies - considered the most emergent among the professional areas - the work overload is frequent. This originates the technostress,a syndrome that affects professionals undergoing intense and continuous contact with digital devices. This type of stress is characterized by a negative psychological state, an abnormal response with specific symptoms related to cardiocirculatory, mental and neurological aspects (Carlotto, 2011; Chen, 2015). Its repercussions influence business as well as the relational sphere causing absenteeism, loss of professional effectiveness, conflict and isolation (Chiappetta, 2017).

The confrontation of such a situation derives from the premises that bring well-being at work as a central element, a concept that emanates from studies and research regarding the perception of quality of life and self-evaluation of personal fulfillment. It is embedded in organizational theories and practices in order to promote transformations in behavioral processes and minimize the occurrence of suffering (Couto\&Paschoal, 2012). 
The promotion of health in the workplace over time has contributed to increase the importance of Well-being at Work (WBW) in face of the new demands of the work environment increasingly implicated in the relation of illness. Given this condition, the relationship between the technological environment and WBW experiences is questioned. Therefore, this study aimed to present the assessment that IT professionals do about the well-being that they experience in their work.

\section{Literature Review}

The well-being construct carries within itself a biopsychosocial perspective applied to personal, professional, financial, family and leisure spheres, among others (Mendonça, Ferreira, Porto \&Zanini, 2012). According to Dessen and Paz (2012), some authors consider well-being as synonymous with happiness, being composed of a current that emphasizes affections and another based on achievement. The frequency with which these factors are perceived by people characterizes the presence of well-being.

Four categories of well-being can serve as a basis for planning health promotion programs in personal life, and especially in work organizations. According to Siqueira and Martins (2013), these categories are: (a) subjective well-being, consisting of three dimensions: general satisfaction with life, positive affections and negative affections. These authors refer that there is still the emotional balance present and this acts as a result of the relationship between the affections. In this category, well-being arises from the experience of positive affections more frequent than negative affections; (b) psychological well-being, composed of cognitive elements that allow the individual to remain healthy; (c) social well-being, the third category, makes it possible to indicate the functioning degree of the individual's social life(Siqueira\& Martins, 2013). Finally, (d) well-being at work, composed of affective bonds directed to work (satisfaction and involvement) and by link to the work environment, represented by organizational commitment, justice and organizational reciprocity (Kanan\&Zanelli, 2012; Siqueira\&Gomide Junior, 2014;Siqueira\& Martins, 2013).

In all areas where well-being issues are considered, the workplace is one of the most significant. This is because a sickly workforce becomes unproductive (Van Dick \& Haslam, 2012). Therefore, it can be observed that health promotion in the workplace is sustained by the inseparability between aspects that come from the organization and the work environment, and the impacts they generate in people's lives.

\subsection{Well-being at Work - WBW}

Understanding the phenomenon of well-being in the work environment implies recognizing the centrality of work for man, identifying the subjectivity present in this relationship and analyzing the relationship between the constituent elements of the world of work (Fernandes \&Vasques-Menezes, 2012).

The presence and manifestation of affection for work resulting in a perception of satisfaction and involvement with work activities characterize two components of well-being at work. The third component relates the worker's commitment to the organization through his/her effort (Ferreira, Silva\& Souza, 2012).

This multidimensional conception is also presented by Siqueira, Orengo and Peiró (2014, p.39). The authors describe the WBW integrated by job satisfaction, engagement with work and affective organizational commitment. They conceive it as a "positive mental state for the possibility of the worker experiencing periods in which, in an interconnected way, positive feelings for aspects present in the work environment emerge within him/her".

The term well-being at work, according Couto and Paschoal (2012, p. 585), is use to indicate "the prevalence of positive emotions and the individuals' perception that, in their work, they develop their potentials and advance in reaching their life goals". Another factor presented by the authors is the influence of working conditions that facilitate or prevent the achievement of goals and positively influence the WBW.

\subsection{Information Technology - IT}

Knowledge, when not accessed and applied, has no value. The importance of information starts to take shape from the moment it transits through networks transforming technology into a medium and knowledge into a capital(Rossetti \& Morales, 2007).

This understanding justifies the high investments that the IT area has received, when the purpose is to increase the competitiveness of an organization in a market marked by innovation and lack of borders (Pereira \& Ferreira, 2015). 
As a result, the specialized professional is entrusted with the task of providing competitive advantage to the organization through the application of his/her knowledge about technological processes (Ferro \&Vanti, 2009). The concept of IT is presented by Veloso $(2007$, p.12) as the "set of devices, services and knowledge related to a particular infrastructure, composed of computers, software, network systems, among others". Besides the technological expansion, the author reports the centrality of man in relation to the machine, the creation of new social spaces and observes the emancipation of individuals through technology.

\section{Method}

It is a research carried out in Brazil, with a quantitative and descriptive approach.283 professionals from nine IT companies participated in the study. The following instruments were used to collect data: (a) socio-professional questionnaire consisting of questions about the characteristics of the participant, the technological environment, the Quality of LifeatWork (QLW) programs offered by the organization and adherence to them; (b) Psychosocial Well-Being Scale (Blanch, Sahagún, Cantera\& Cervantes, 2010) composed of 22 items, in a partial version (excluding 'affection' and 'competency' dimensions) and (c) Maslach Burnout Inventory - MBI (Schaufeli, Leiter, Maslach\& Jackson, 1996) associated with the Utrech Work Engagement Scale - UWES Questionnaire (Schaufeli, Bakker\&Van Rhenen, 2009; Schaufeli, Salanova, González-Roma, \& Bakker, 2002).

The results obtained through these questionnaires were tabulated and analyzed in categories thus distributed:

- MBI Questionnaire: (a) dimension Exhaustion composed of items 1, 2, 3, 4 and 6; (b) Effectiveness dimension represented by questions 5, 7, 10,11, 12 and 15; and (c) Cynicism dimension composed of items 8, 9, 13 and 14 of the questionnaire. The results obtained will be presented and evaluated by these categories.

- UWES Questionnaire: formed by three dimensions, namely: (a) Vigor, represented by questions 16, 19, 23, 27, 30 and 32; (b) The second dimension is the Dedication composed of questions 17, 20, 22, 25 and 28 and, finally, (c) Absorption dimension characterized by questions 18, 21, 24, 26, 29 and 31. The quantitative obtained through these questions was analyzed by categories and not in an individualized way.

The set of instruments described above follows the model proposed by the International Study on Quality of Life in Work in Public Organizations of Human Services - WONPUM. The data were analyzed in Statistical Package for Social Sciences (SPSS) statistical software. The descriptive statistics of the socio-professional data and perceptions of QLW actions were initially performed. Subsequently, the mean and standard deviation for instrument dimensions were established. The normality of the data was evaluated by the Kolmogorov-Smirnov and Shapiro-Wilk tests. Due to the non-normality of the data, non-parametric statistics were used, through the Mann-Whitney and Kruskal-Wallis tests, to evaluate the mean of the instrument dimensions in relation to gender, age and working time in the company, with a significance level of $5 \%$.

\section{Results}

Of the nine companies surveyed, seven are classified as medium-sized (up to 99 employees) and two are large companies (over 100 employees). The average time of existence of these companies is 19 years. On average, they have 79 professionals dedicated exclusively to IT activities.

The profile of the respondents is characterized by professional men, single, young adults, with undergraduate level of education. Regarding the working time in the IT company, the majority work for one year to five years (Table 1).

Table 1- Descriptive analysis of socio-professional aspects

\begin{tabular}{|c|c|c|}
\hline Variables & $\mathbf{n}$ & $\%$ \\
\hline \multicolumn{3}{|l|}{ Gender (283) } \\
\hline Male & 217 & 76.7 \\
\hline Female & 66 & 23.3 \\
\hline \multicolumn{3}{|l|}{ Age (278) } \\
\hline$<=29$ & 197 & 70.9 \\
\hline $30-39$ & 68 & 24.9 \\
\hline 40 or more & 13 & 4.7 \\
\hline Marital Status (278) & & \\
\hline
\end{tabular}


Single

Married

Separated

Stable Union

Education (263)

High School / Technical Education Completed

Incomplete undergraduate course

Complete undergraduate course

Graduate Studies

Working time at company (277)

Up to 1 year

Between 1 and 5 years

More than 5 years
181

81

2

14

1

13

200

49

39

173

65
65.1

29.1

0.7

5.0

0.4

4.9

76

18.6

14.1

62.5

23.5

Regarding the professionals' perceptions about the QLW actions offered by the company, the majority reports that they know them. However, in relation to adherence to these actions, $84 \%$ self-refer their adhesion between low and regular extracts (Table 2).

Table 2 - Descriptive analysis of the perception about QLW actions

\begin{tabular}{lcc}
\hline \multicolumn{1}{c}{ Variables } & n & $\%$ \\
\hline Knows QLW actions (277) & 234 & 84.5 \\
Yes & 43 & 15.5 \\
No & & \\
QLW actions consider the characteristics of the & & \\
technological environment (227) & 180 & 79.3 \\
Yes & 47 & 20.7 \\
No & & \\
Adhesion to QLW actions (267) & 9 & 3.4 \\
Very High & 19 & 7.1 \\
High & 125 & 46.8 \\
Regular & 99 & 37.1 \\
Low & & \\
\hline
\end{tabular}

The overall mean of the expectations factor of the well-being questionnaire (qBLG) was 4.93 (sd 1.04). Table 3 shows the average and standard deviation of the dimensions evaluated by means of different instruments in relation to the gender variable. Statistical significance was observed only for the effectiveness dimension, with men evaluating it more positively.

Table 3 - Comparative analysis between men and women

\begin{tabular}{llccccc}
\hline & \multicolumn{1}{c}{ Variables } & \multicolumn{2}{c}{ Male } & \multicolumn{2}{c}{ Female } & \multirow{2}{*}{ p-value } \\
\cline { 3 - 6 } & Average & sd & Average & sd & \\
\hline \multirow{2}{*}{ MBLG } & Expectations dimension & 4.97 & 1.02 & 4.83 & 1.13 & 0.401 \\
\hline \multirow{2}{*}{ UWES } & Exhaustion & 2.40 & 0.88 & 2.42 & 0.96 & 0.823 \\
& Effectiveness & 4.71 & 0.74 & 4.48 & 0.68 & $0.017^{*}$ \\
& Cynicism & 2.11 & 0.89 & 2.10 & 0.82 & 0.933 \\
\hline \multirow{2}{*}{ Vigor } & Dedication & 4.30 & 0.82 & 4.05 & 1.01 & 0.052 \\
& Absorption & 4.41 & 0.99 & 4.25 & 1.01 & 0.275 \\
& 3.96 & 0.82 & 3.84 & 0.94 & 0.365 \\
\hline
\end{tabular}

${ }^{a}$ non-parametric Mann-Whitney test 
When compared by age groups (Table 4), the professionals who presented significantly more vigor were the older ones compared to the younger ones. As far as the dedication dimension is concerned, the youngest are the least dedicated, differing significantly from the other two age groups. In relation to the last dimension, absorption, again the participants of greater age group obtained the highest averages, followed by professionals of intermediate age group (30-39 years).

Table 4 - Comparative analysis by age group

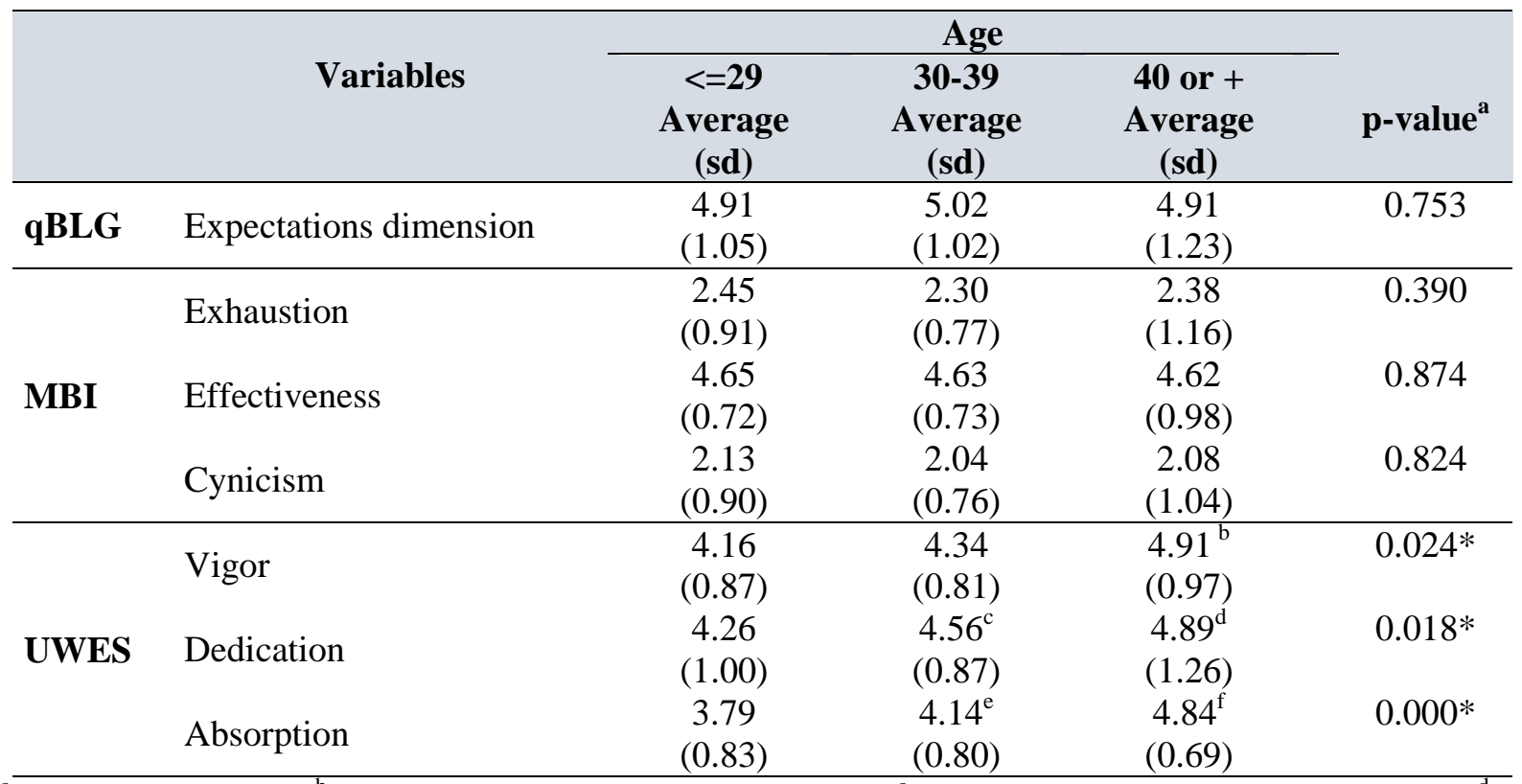

${ }^{\mathrm{a}}$ Kruskal-Wallis test $/{ }^{\mathrm{b}}$ Significance between groups 1 and $3 /{ }^{\mathrm{c}}$ Significance between groups 1 and $2 /{ }^{\mathrm{d}}$ Significance between groups 1 and $3 /{ }^{\mathrm{e}}$ Significance between groups 1 and $2 /{ }^{\mathrm{I}}$ Significance between groups 1 and 3

Finally, Table 5 presents the comparison between the dimensions considering the working time in the company. Statistical significance was observed only for the effectiveness dimension, with the highest averages found for professionals working in the company for 1 and 5 years (4.72), followed by those who work in the company for more time (4.66).

Table 5 - Comparative analysis by working time

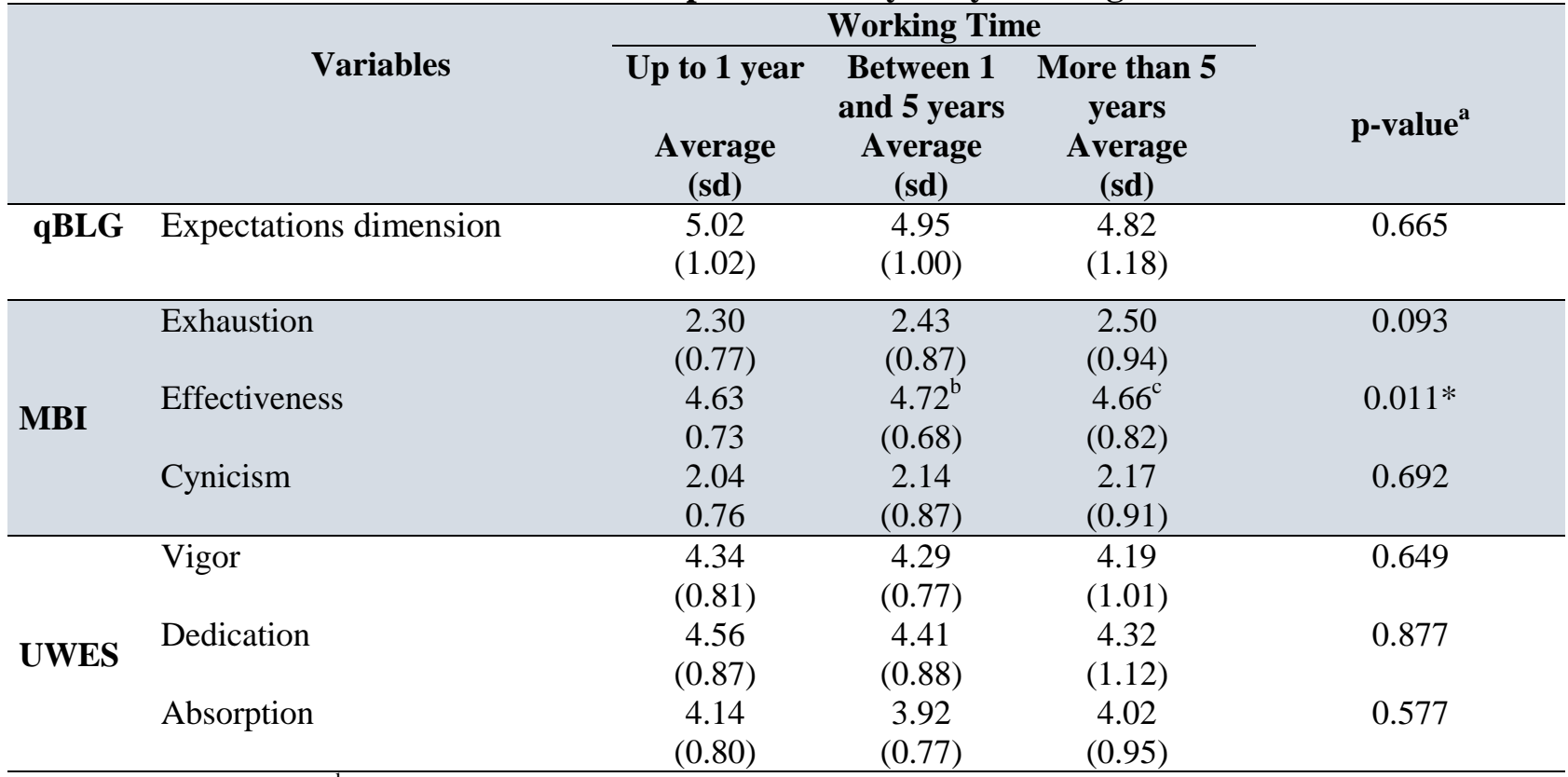

${ }^{\mathrm{a}}$ Kruskal-Wallis Test $/{ }^{\mathrm{b}}$ Significance between groups 1 and $2 /{ }^{\mathrm{c}}$ Significance between groups 1 and 3 


\section{Discussion}

The revolution promoted by the development of technology has generated impacts in the personal, social and work spheres. According to Neves (2008, p. 6), the emergence of a technology based on a flexible market favored the creation of new jobs and offer of qualification, which the author called a "cognitive society, focused on the production and exchange of knowledge". Changes from technology are inevitable, and for the competitive survival of companies, it is important to meet human and organizational needs in tune (Neves, 2008).

Technological making requires cognitive requirements and is faced with internal and external stimuli which can generate stress and other disorders derived from them. Identifying risk factors, the profile of the professionals in the area, the environment in which the work is carried out and the intervening factors in this work allows health actions to be planned in a preventive way to the technostress (Carlotto, 2011; Chen, 2015).

Inserted in this context of pressures for creativity associated with productivity, the professionals of this study are characterized by male predominance, corroborating with what is found in the literature of the area. One of the reasons for this inequality may be related to socio-historical issues of the construction of masculine and feminine identities (Castro, 2013; Nunes, 2016; Silva, Silva \& Brito, 2017). Another aspect related to the greater participation of men in the IT area is the applied rationality as opposed to attributes such as emotionality, interactivity and personal relationships, predominantly female characteristics (Nunes, 2016), and the existence of stereotypes that show technical aspects as unattractive to women (Nunes et al., 2015; Campbell \&Herlihy, 2016).

Still with regard to the profile of the participants, a high index of young people was found, a result that resembles the study of Lima and Oliveira (2017) and that of Soares, Capistrano and Barbosa (2015). The age range between 18 and 29 years old represents the period of life of beginning and finishing the academic formation, courses of improvement and entrance in the labor market. This generation, known as Generation Y, is characterized by work behaviors marked by innovation, flexibility and mobility, by constant contact with technology, rapid learning, anxiety, non-submission to meaningless work, commitment to the career and not to the company, and selforiented posture (Lima \& Oliveira, 2017; Muller \&Dewes, 2012). This understanding is reinforced by the lower indexes of engagement in three dimensions that were found among the participants of this age group.

The largest number of participants was found (62.5\%) regarding the working time in the organization between one and five years. In this regard, it must be considered that turnover is substantial in the area of IT, either because of the competitiveness among organizations, the lack of this professionals in the labor market, the attraction by the public sector and its advantages, or the interest in starting a business of his/her own (Coobs, 2009; Fink \& Neumann, 2007; Softex, 2012). The lowest percentage of professionals with more than five years of work in the organization $(23.5 \%)$ confirms this understanding.

The average found in the evaluation of psychosocial well-being was 4.93 (sd 1.04), which reflects a certain balance between the expectations of IT professionals and what they actually experience in the work context. Overall, this average is a positive indicator of well-being for IT professionals. These results corroborate the contributions of Paschoal and Tamayo (2008) regarding well-being to identify the predominance of elements of positive emotion together with the possibility of accomplishment, to develop potentials and skills in the labor context.

In a paper on the main trends and theoretical perspectives regarding quality of life at work and well-being, Ferreira, Silva and Souza (2012, p. 90) present the psychosocial context as one of the dimensions of the Martel and Dupuis (2006) approach, which presents the domains of belonging feeling, emotions aroused by work, competition, relationships with colleagues, relationships with supervisors and relationships with employers as components of the social and organizational sphere related to the quality of life and the perception of well-being at work. Similarly, it is possible to transpose such an understanding to the findings of this study, since the affirmations signaled by the participants in the Expectations dimension are consistent with the statements made by the authors mentioned.

One of the hypotheses for this result may be associated with coping strategies used in the work environment. Such strategies can positively mediate the stressful factors of the environment and the professional, resulting in the absence of a negative perception of the psychosocial well-being in relation to their work. 
Participants reveal that they are aware of the QLW actions offered by the organization and that such actions are consonant with the characteristics of the technological environment. However, a large majority reported not adhering to such actions. On the technological context, Porto, Tamayo and Paschoal (2012) cite the personenvironment congruence in terms of compatibility of characteristics between individual and environment, and the effect of this relationship on well-being. The resulting opposite phenomenon, that is, an incongruence in this relationship, can be perceived through exhaustion, a feeling of ineffectiveness, low productivity, allowing the worsening of stress and the appearance of Burnout. The results of this study differ from such a postulate, since even if they do not adhere to QLW programs, the participating professionals reveal a positive evaluation for the psychosocial well-being. It suggests the need for a deepening of research with the exploration of the theme in order to know its reasons and the motivations for the refusal to participate.

The presence of Burnout will occur where the exhaustion and cynicism scores are high and the effectiveness scores are low. Exhaustion is thought to be a consequence of continued losses and frequent threats to the environment, resulting in a loss of resources between professionals (Robert \&Vandenberghe, 2017).

The comparative analysis between men and women IT professionals from the three instruments used to evaluate Burnout presents significance only for Effectiveness, a factor that portrays how much the professionals feel accomplished, competent and involved with the work they perform (Ronchi, 2012). Under this condition, men presented an average higher than women, emphasizing more expressively the expectations they place on the work they perform. Effectiveness at work is related to the existence (or not) of work resources, including autonomy, performance feedback and social support. Under this condition, perceived effectiveness is associated with turnover prediction (Bakker, Demerouti\&Schaufeli, 2002). It can be seen that the lower effectiveness factor found among women working in IT contributes to the maintenance of the reduced percentage of their participation in this professional segment.

Emotional exhaustion is the most important, analyzed and reported aspect of Burnout (Maslach, Schaufeli\&Leiter, 2001). It is defined as lack of emotional resources (González-Romá, Schaufeli, Bakker\&Lloret, 2006) or energy (Cordes\& Dougherty, 1993). It is believed that this exhaustion is caused by continued losses and constant threats from the environment, which ultimately result in a loss of resources among individuals (Hobföll\&Freedy, 1993).

In the negative dimensions of the scales, the highest averages for Exhaustion (2.5) and Cynicism (2.17) are among professionals who have more than 5 years of working time in the company. This fact may reflect that the intense contact between men and technology results in physical and/or emotional exhaustion. This is something that requires attention of managers, since a person with a high rate of exhaustion is expending forces beyond their limits and uses all physical and emotional resources, resulting in psychic or physical symptoms (Ronchi, 2012).

The evaluation of the respondents indicates prevalence of positive and healthy aspects distancing the presence of Burnout syndrome among these professionals. However, it does not detract attention to the other dimensions that aim to evaluate negative aspects since, if not given due attention, these can stand out in the future, resulting in physical, mental and productivity losses for the company.

The search for increasing attention on the positive aspects of work, from the studies on Burnout, derived research on engagement. Engagement in work refers to a positive psychological state related to the professional environment, and it consists of three dimensions: vigor, dedication and absorption (Salanova \& Schaufeli, 2009). The engagement results show that, in all three categories that are part of the scale, the highest averages were those of the male respondents. The absorption dimension showed a smaller difference between the averages of men and women, which means that both attribute meaning and purpose, feel enthusiastic, inspired, proud and challenged in the work they do, very closely.

The evaluation of this construct with IT professionals made it possible to reflect on the meaning of the work that these professionals perform, regardless of gender, and that indicate how much they feel involved with their activities. However, it is known that other social roles fall on women, which can contribute to an overload and affect the level of vigor directed to work. The evaluation of the behavior of engagement in the work corroborated with the analysis of the results presented for the Expectations and Effectiveness dimensions, for men and women, categories with expressive results. 
This fact allows establishing a relationship between them, since the professional that demonstrates a high degree of expectations and seeks their concreteness, increases the probability of performing an effective work, engaged with his/her purposes and the purposes of the organization.

However, it points to the relevance of the percentages of all indicators that, however small, suggest preventive behavior so that these indexes do not increase. In this regard, Kanan and Arruda (2013) argue that the consequences of the digital age in working relationships impact the health of the worker to some degree. For the authors, the sickness of a significant number of workers stems from the precariousness of work, even if an important repertoire of technological resources is present or determines their work processes.

When evaluating the indexes obtained in the engagement scale, in the item Vigor, there is a predominance of positive perception regarding each aspect evaluated in the category. The frequency of responses ranged from 'often' to 'always', which depicts the perception of energy, vigor to work, resistance to working long periods of time, persistence even when something does not work well, which translates into high capacity of resilience.

The comparative analysis between the instruments used in this study in relation to the age groups reveals significance for vigor, dedication and absorption, elements that translate the engagement in the work, in professionals aged 40 years or over. The perception of positivity and work-related satisfaction found with this group of participants is reflected in the affirmations regarding high levels of energy and mental resilience, perseverance in the face of obstacles, identification and consequent investments in work, enthusiasm, inspiration and feeling proud for the activities carried out, at the time when absorption by them is evident (Schaufeli, Bakker \& Salanova, 2006; Schaufeli, González-Romá, Bakker, 2002). It should be noted that untimely, the sense of urgency, the need for mobility, flexibility, non-submission (Lima \& Oliveira, 2017; Muller \&Dewes, 2012), among other characteristics of Generation Y, represented by the lower age range in this study, are important counterpoints to the results found, which may justify them.

Another example of the psychic suffering resulting from the man-machine relationship - already presented in this study and which reinforces the reading of the data obtained - is illustrated by Carlotto (2011), Chen (2015) and Chiappetta (2017) by highlighting the impact of the use of technologies in the techno stress format, which reveals the presence of different stress indicators between men and women and their coping strategies. As a result, evidence of stress, forms of individual coping among men and emotional coping among women are evident (Carlotto, 2011). And, as advocated by Copari et al. (2017), the speed of information and communication technologies development is much greater than the advance of health sciences.

In summary, in a reading of the results obtained for all the components of this factor, it is possible to conclude that the perception of the respondents was of positive predominance, indicating no signs of severe illness.

\section{Conclusions}

The results of the study point out a healthy outlook for IT professionals in a technology environment. However, the possibility of health promotion and prevention of illness cannot be ruled out, based on lower registered indicators.

The predominance of positive results in this research endorses the perspective of Positive Psychology, which directs the focus to people to stimulate the promotion of healthy aspects of the human being. In this perspective, besides the financial return, people can have a positive psychological return, being aware of their work environment and its consequences (Snyder \& Lopez, 2009).

It is concluded that promoting and expanding WBW preventive actions are strategic managerial decisions, since WBW is directly related to the nature of the activity and the technology environment. Faced with a promising scenario of expansion of the technological area and the highly logical-rational demand that characterizes it, the tendency to increase physical and psychic efforts is a reality to be managed. Given this scenario, balancing health and productivity is a healthy and effective alternative for both workers and organizations when considering, for example, attracting and retaining talent. 


\section{References}

Bakker, A.B., Demerouti, E.\&Schaufeli, W.B. (2002). Validation of Maslach Burnout Inventory - general survey an internet study. Anxiety Stress \& Coping, 15(3), 245-260.

https://doi.org/10.1080/1061580021000020716.

Blanch, J. M., Sahagún, L. C. \& Cervantes, G. (2010). Cuestionário de Bienestar Laboral General: Estructura Y Propriedades Psicométricas. Revista de PsicologíadelTrabajo y de lasOrganizaciones. 26, 157-170. Available: http://www.redalyc.org/pdf/3953/395335581002.pdf

Campbell, L. O. \&Herlihy, C. (2016). An analysis of the media's sociocultural influence of women in technology: implications for educators. Society for Information Technology \& Teacher Education International Conference, p. 474-478.Available:https://www.learntechlib.org/primary/p/172313/

Carlotto, M. S. (2011). Tecnoestresse: diferenças entre homens e mulheres. Revista Psicologia: Organizações e Trabalho. 11, 51-64. Available:http://pepsic.bvsalud.org/scielo.php?script=sci_arttext\&pid=S1984$66572011000200005 \& \operatorname{lng}=$ pt\&tlng=pt.

Castro, B. G. (2013). Performances de gênero no setor de Tecnologia da Informação: estratégias de mulheres em um universo de trabalho dominado por homens. Seminário Internacional Fazendo Gênero 10 (Anais Eletrônicos), Florianópolis. Available:

http://www.fazendogenero.ufsc.br/10/resources/anais/20/1382034407_ARQUIVO_Performancesdegeneronose tordeTecnologiadaInformacao.pdf.

Chen, L. (2015). Validating the technostress instrument using a sample of Chinese knowledge

workers. Journal of International Technology and Information Management, 24(1), 5. Available: http://scholarworks.lib.csusb.edu/jitim/vol24/iss1/5.

Chiappetta, M. (2017). The Technostress: definition, symptoms and risk prevention. Senses and Sciences, 4(1) 358-361. doi: 10.14616/sands-2017-1-358361

Coombs, C. R. (2009). Improving retention strategies for IT professionals working in the public sector.Information \& Management, v. 46, n. 4, p. 233-240. https://www.sciencedirect.com/science/article/pii/S0378720609000342

Coppari, N., Bagnoli, L., Codas, G., Montanía, M., Martinez, U. \&Humada, H. L. (2017). Uso de Tecnologías de laComunicación e Información y Tecnoestrésen Estudiantes Paraguayos: surelaciónconlaedad. Cuadernos de Neuropsicología/Panamerican Journal of Neuropsychology, 11(3). Available: http://www.cnps.cl/index.php/cnps/article/view/306/325

Cordes, C. L., \& Dougherty, T. W. (1993).A review and an integration of research on job burnout.Academy of Management Review, 18(4), 621-656.https://doi.org/10.5465/amr.1993.9402210153

Couto, P. R. \& Paschoal, T. (2012). Relação entre ações de qualidade de vida no trabalho e bem-estar laboral. Rev. Psicol. Argum, Curitiba, 30, 585-593. Available: https://periodicos.pucpr.br/index.php/psicologiaargumento/article/view/20563

Dessen, M. C., Neiva, E. R. \& Paz, M. G. T. (2012). Bem-estar e felicidade nas organizações: um só fenômeno? Em: M.C. Ferreira, H. Mendonça. (Orgs.) Saúde e bem-estar no trabalho: dimensões individuais $e$ culturais (pp.105-130). São Paulo: Caso do Psicólogo.

Dias, P. A. S. \& Freitas, J. A. S. B. (2010). O que querem os Analistas de Sistemas? Expectativas, Identificações e Vínculos com o Trabalho e com as Organizações. Rev. Adm. Made, 14(1), 23-36. Available: revistadireitobh.estacio.br/index.php/admmade/article/view/62

Farsen, T. C., Costa, A. B., \& Silva, N. (2018). Resiliência no trabalho no campo da Psicologia. Psicologíadesdeel Caribe, 35(1). Available: https://search.proquest.com/openview/9d6615e64e8ee4d50a15322bab12615d/1?pqorigsite $=$ gscholar $\&$ cbl $=2027439$

Fernandes, S. R.P. \& Vasques-Menezes, I. (2012). Organização do trabalho: implicações para a saúde do trabalhador. Em: M. C. Ferreira. \& H. Mendonça (Orgs.) Saúde e bem-estar no trabalho: dimensões individuais e culturais (pp.261-275). São Paulo: Caso do Psicólogo.

Ferreira, M. C., Silva, C. A. \& Souza, M. A. (2012). Qualidade de vida e bem-estar no trabalho: principais tendências e perspectivas teóricas. In: M. C. Ferreira \& H. Mendonça. (Orgs.) Saúde e bem-estar no trabalho: dimensões individuais e culturais. São Paulo: Caso do Psicólogo. 
Ferro, C. \&Vanti, A. A. (2009). A Administração da Tecnologia da Informação e a Gestão de Recursos Humanos.In: C. Bittencourt \& (cols). Capítulocomplementar 25.[CD].

Fink, L. \& Neumann, S. (2007). Gaining agility through IT personnel capabilities: the mediating role of IT infrastructure capabilities.Journal of the Association for Information Systems, 8(8), p. 440-462. doi: $10.17705 / 1$ jais.00135

González-Romá, V., Schaufeli, W. B., Bakker, A. B., \&Lloret, S. (2006). Burnout and work engagement: Independent factors or opposite poles?. Journal of Vocational Behavior, 68(1), 165-174. https://doi.org/10.1016/j.jvb.2005.01.003

Hobföll, S. \&Freedy, J. (1993). Conservation of resources: A general stress theory applied to burnout. In: Schaufeli, W, Maslach, C, Marek, T (eds) Professional Burnout: Recent Developments in Theory and Research. Washington, DC: Taylor \& Francis, 115-134.

Kanan, L. A., \& de Arruda, M. P. (2013). A organização do trabalho na era digital. Estudos de Psicologia, 30(4), 583-591. http://dx.doi.org/10.1590/S0103-166X2013000400011

Kanan, L. A. \&Zanelli, J. C. (2012). Características do trabalho de coordenadores de curso no contexto universitário. Revista Espaço Pedagógico, 18(1).Available: http://www.seer.upf.br/index.php/rep/article/view/2072

Kanan, L. A.\&Marcon, S. A. (2017). Ambiente, Saúde e Gestão Humana de Recursos: cartografia do bem-estar no trabalho. In: Pedro Parreira, LiseteMónico e Cara Carvalho. (Org.). Gestão de Pessoas nas Organizações. 1ed. Coimbra - Portugal: Editora da Escola Superior de Enfermagem de Coimbra Portugal, v. 1, pp. 75-96.

Lima, J. C., \& Oliveira, D. R. D. (2017). Trabalhadores digitais: as novas ocupações no trabalho informacional. Sociedade e Estado, 32(1), 115-143. http://dx.doi.org/10.1590/s0102-69922017.3201006

Martel, J. P., \&Dupuis, G. (2006). Quality of work life: Theoretical and methodological problems, and presentation of a new model and measuring instrument. Social indicators research, 77(2), 333-368. doi $10.1007 / \mathrm{s} 11205-004-5368-4$

Maslach, C., Schaufeli, W. B., \&Leiter, M. P. (2001).Job burnout. Annual review of psychology, 52(1), 397422.https://doi.org/10.1146/annurev.psych.52.1.397

Mendonça, H., Ferreira, M. C., Porto, J. \&Zanini, D. S. (2012) Saúde, qualidade de vida e bem-estar: limites e interfaces teórico-metodológicas. In: M. C. Ferreira \& H. Mendonça (Org.) Saúde e bem-estar no trabalho: dimensões individuais e culturais. São Paulo: Caso do Psicólogo.

Müller, J. \&Dewes, F. O. (2012).Impacto da Inserção da Geração Y no Mercado de Trabalho. Universo Acadêmico, Taquara, 5(1). Available: https://www2.faccat.br/portal/sites/default/files/ckeditorfiles/ua2012_jmuller_fdewes.pdf

Neves, M. F. (2008) Inserção de profissionais com alta qualificação na área de Tecnologia da Informação. Trabalho de conclusão de curso em Ciências Sociais pela Universidade Federal do Rio Grande do Sul, Porto Alegre, RS. Available: http://www.lume.ufrgs.br/bitstream/handle/10183/17536/000718790.pdf?sequence=1

Nunes, J. H. (2016). Gênero e raça no trabalho em tecnologia da informação (TI). Ciências Sociais Unisinos, 52(3).https://doi.org.10.4013/csu.2016.52.3.09

Nunes, M. M. et al. (2015). Uma iniciativa para atrair as estudantes do ensino médio para a Área de Tecnologia da Informação. In: Workshop de Informática na Escola. Anais... p. 425. https://doi.org/10.5753/cbie.wie.2015.425

Paschoal, T. \&Tamayo, A. (2008). Construção e validação da escala de bem-estar no trabalho. Avaliação psicológica, 7(1). Available: http://pepsic.bvsalud.org/scielo.php?script=sci_arttext\&pid=S167704712008000100004\&lng=pt\&nrm=iso.

Pereira, C., \& Ferreira, C. (2015). Identification of IT value management practices and resources in COBIT 5. Revista Ibérica de Sistemas e Tecnologias de Informação, (15), 17-33. Available:https://search.proquest.com/docview/1707142482?accountid=146869

Porto, J. B., Tamayo, M. R. \& Paschoal, T. (2012) Em: M. C. Ferreira \& H. Mendonça (Orgs.) Saúde e bem-estar no trabalho: dimensões individuais e culturais. São Paulo: Caso do Psicólogo.

Robert, V. \&Vandenberghe, C. (2017). L'affectivité positive etnégative: desfacteurs de protection ou de vulnérabilité à l'engagementautravail. Psychologie $d u$ Travail et des Organisations. https://doi.org/10.1016/j.pto.2017.04.001 
Ronchi, C. J. (2012). Sentido do Trabalho: saúde e qualidade de vida. Curitiba: Juruá.

Rossetti, A. G., \& Morales, A. B. T. (2007). O papel da tecnologia da informação na gestão do conhecimento. Ciência da Informação, 36(1), 124-135.Available: http://www.scielo.br/pdf/ci/v36n1/a09v36n1

Salanova, M., \&Schaufeli, W. (2009). El engagementeneltrabajo: cuandoeltrabajo se convierteenpasión. Alianza editorial.

Schaufeli, W. B., Bakker, A. B.\& Van Rhenen, W. (2009). How changes in job demands and resources predict burnout, work engagement, and sickness absenteeism. Journal of Organizational behavior, 30(7), 893917.doi: 10.1002/job.595

Schaufeli, W. B., Bakker, A. B., \&Salanova, M. (2006). The measurement of work engagement with a short questionnaire: A cross-national study. Educational and psychological measurement, 66(4), 701-716.doi: $10.1177 / 0013164405282471$

Schaufeli, M.P. Leiter, C. Maslach, S.E. Jackson (1996). The MBI-General Survey. In:

C. Maslach, S.E. Jackson, M.P. Leiter (Eds.), Maslach Burnout Inventory manual (3rd ed.), Consulting Psychologists Press.

Schaufeli, W. B., Salanova, M., González-Romá, V., \&Bakker, A. B. (2002). The measurement of engagement and burnout: A two sample confirmatory factor analytic approach. Journal of Happiness studies, 3(1), 7192. https://doi.org/10.1023/A:1015630930326

Silva, M. S., Silva, A. S., \& Brito, S. R. (2017). A participação feminina nos cursos de computação do estado do Pará: avanços e desafios. In ColloquiumExactarum . 9(1), 01-13.

Available:http://revistas.unoeste.br/revistas/ojs/index.php/ce/article/viewArticle/1594

Silva, M., Queirós, C., Cameira, M., Vara, N., \& Galvão, A. (2015). Burnout e Engagement em profissionais de saúde do interior: norte de Portugal. Psicologia, Saúde\&Doenças, 16(3), 286-299. Available:http://www.scielo.mec.pt/scielo.php?script=sci_arttext\&pid=S1645$00862015000300002 \& \operatorname{lng}=\mathrm{es} \& \operatorname{lng}=\mathrm{pt}$

Siqueira, M.M.M.\& Gomide Junior, S. (2014). Vínculos do indivíduo com o trabalho e com a organização. In: J. C. Zanelli, J. E. Borges-Andrade \&A.V.B.Bastos.(2014).Psicologia, Organizações e Trabalho no Brasil.(pp. 316-348). Porto Alegre: Artimed.

Siqueira, M. M, Orengo, \&Peiró (2014). Bem-estar no trabalho. In M. M. Siqueira (Org.), Novas medidas do comportamento organizacional. Porto Alegre: Artimed.

Siqueira, M. M. M. \& Martins, M. C. F. (2013) Promoção de saúde e bem-estar em organizações. In: L. O. Borges, \& L. Mourão (Orgs.) O trabalho e as organizações: atuações a partir da psicologia. Porto Alegre: Artmed.

Snyder, C. R. \& Lopez, S. J. (2009). Psicologia Positiva: uma abordagem científica e prática das qualidades humanas. Porto Alegre: Artmed.

Soares, M. L., Capistrano, A. G. A. \& Barbosa, M. B. A. (2015). A rotatividade de servidores públicos na área de ti: um estudo de caso sobre a ótica da gestão de pessoas. Available:https://repositorio.ufsc.br/xmlui/handle/123456789/136139

Softex, Observatory. (2012). Software e serviços de TI: a indústria brasileira em perspectiva $n^{\circ}{ }^{\circ}$ 2. Campinas: Observatório Sofitex.

Van Dick, R. \& Haslam, S. A. (2012). Stress and well-being in the workplace: Support for key propositions from the social identity approach. In: J. Jetten., C. Haslam, \& S. A. Haslam. The social cure: Identity, health and well-being, (pp. 175-194). New York, NY, US: Psychology Press.

Veloso, R. (2007). As potencialidades contraditórias das tecnologias da informação. Contemporânea. 5(2), 921.Available:http://www.contemporanea.uerj.br/pdf/ed_09/contemporanea_n9_09_rveloso.pdf.

Zanelli J. C. \&Kanan, L.A. (2018). Fatores de risco, proteção psicossocial e trabalho: organizações que emancipam ou que matam. Lages: Uniplac. 